\title{
JARINGAN SOSIAL PETANI DALAM DISTRIBUSI HASIL PRODUKSI GARAM DI GAMPONG TANOH ANOE KECAMATAN JANGKA KABUPATEN BIREUEN
}

\author{
Nailul Rahmi, Amiruddin Ketaren *) \\ ${ }^{*}$ Program Studi Sosiologi Universitas Malikussaleh, ketarenamiruddin@ gmail.com
}

\begin{abstract}
This research was conducted to see how the social network of salt farmers in distributing salt production and their efforts to maintain the existing social networks between salt farmers and distributors. The theory is based on Barry Wellman's theory of interconnecting social networks between actors. Data collection uses non-participant observation methods, namely researchers directly observe how the informants behave and gain direct experience, making it easier for researchers to perform data analysis. The analysis uses descriptive qualitative methods, namely with the aim of providing an overview of social problems through data in the form of descriptions of words or pictures. From the research results, it can be concluded that there are two forms of salt farmer network, namely the network with salt muge and the network with UD Milhy Jaya. As for the efforts to maintain the social network of salt farmers, namely by trust, increasing productivity, improving quality, and determining prices.
\end{abstract}

Keywords: Social Network, Salt Farmers, Distribution

\begin{abstract}
ABSTRAK
Penelitian ini dilakukan dengan tujuan agar dapat melihat bagaimana jaringan sosial petani garam dalam mendistribusikan hasil produksi garam dan upaya mempertahankan jaringan sosial yang sudah ada antara petani garam dengan distributornya. Teori yang menjadi landasan penelitian ini adalah teori Barry Wellman tentang jaringan sosial yang saling menghubungkan antar aktor. Pengumpulan data memakai metode observasi non-partisipan yaitu peneliti mengamati langsung bagaimana perilaku dari informan dan memperoleh pengalaman langsung sehingga memudahkan peneliti dalam melakukan analisis data. Analisis menggunakan metode kualitatif deskriptif yaitu dengan tujuan memberikan sebuah gambaran tentang masalah sosial melalui data berbentuk uraian kata-kata ataupun gambar. Dari hasil penelitian dapat disimpulkan bahwa bentuk jaringan petani garam ada dua yaitu jaringan dengan muge garam dan jaringan dengan UD Milhy Jaya. Adapun upaya mempertahankan jaringan sosial petani garam yaitu dengan kepercayaan, meningkatkan produktivitas, meningkatkan kualitas, dan penentuan harga.
\end{abstract}

Kata Kunci: Jaringan Sosial, Petani Garam, Distribusi 


\section{PENDAHULUAN}

Garam merupakan komoditas yang sangat penting bagi kehidupan masyarakat. Selain untuk konsumsi, garam diperlukan oleh industri, diantaranya untuk pengawetan dan campuran bahan kimia. Banyaknya kebutuhan garam membuat negara harus mendorong produksi demi memenuhi kebutuhan garam nasional. Ditunjang oleh kekayaan alam yang menjadi modal utama produksi garam, Indonesia seharusnya mampu memproduksi garam sendiri, namun pada kenyataannya Indonesia masih mengimpor garam (Departemen Perindustrian, 2009). Pada tahun 2013 kebutuhan garam di dalam negeri mencapai 3 juta ton per tahun dengan rincian 1,4 juta ton untuk garam konsumsi dan 1,6 juta ton untuk garam industri. Sementara produksi garam rakyat pada tahun 2013 tercatat sebesar 1.319.607 ton. Artinya dari segi produksi, Indonesia belum mampu mencukupi kebutuhan nasional, sehingga impor menjadi salah satu solusi jangka pendek (BPS, 2014).

Ujung tombak produksi garam adalah petani garam. Mereka mengusahakan produksi garam sebagai pelaku ekonomi yang bebas dan mandiri (Soetoprawiro, 2013). Masyarakat Gampong Tanoh Anoe Kecamatan Jangka Kabupaten Bireuen umumnya bermata pencaharian sebagai petani garam. Data monografi Gampong Tanoh Anoe menunjukkan luas wilayah 45,5 Ha, dengan pemanfaatan luas tanah di wilayah Gampong Tanoh Anoe adalah sebagai berikut: 1) tanah tambak: 10,374 Ha, 2) tanah pekarangan/bangunan: 20,847 Ha, 3) tanah kuburan: 2,0 Ha, 4) tanah lahan produksi garam: 12,278 Ha. Perbandingan ini menunjukkan besarnya potensi Gampong Tanoh Anoe di bidang perikanan dan pertanian garam. Oleh karena itu, masyarakat Gampong Tanoh Anoe sebagian besar berprofesi sebagai petani garam. Ada sebanyak 180 jiwa dari 878 jiwa jumlah keseluruhan penduduk Gampong Tanoh Anoe Kecamatan Jangka Kabupaten Bireuen yang berprofesi sebagai petani garam (Data Gampong Tanoh Anoe, 2020).

Bermata pencaharian petani garam sudah dilakoni oleh masyarakat di Gampong Tanoh Anoe secara turun temurun. Letak kawasan gampong yang berada di pesisir memudahkan akses petani untuk bertani garam. Profesi ini telah dijalankan oleh penduduk berpuluh-puluh tahun lamanya. Maka tidak heran jika banyak petani yang berusia lanjut masih bekerja di ladang penggaraman. Tidak hanya petani yang berusia lanjut, generasi muda tidak ketinggalan mengikuti jejak keluarga yang telah lama berprofesi sebagai petani garam (Observasi, 03/03/2020).

Berdasarkan hasil observasi awal yang peneliti lakukan di Gampong Tanoh Anoe, terdapat 96 pondok yang memproduksi garam. Dalam setiap harinya satu orang petani garam dapat memproduksi $120 \mathrm{Kg}$ garam. Besarnya kuantitas produksi garam membuat para petani garam tersebut harus pandai membangun jaringan sosial dengan para distributor yang mendistribusikan hasil produksi garam. 
Berbicara tentang jaringan sosial, masyarakat pesisir di Gampong Tanoh Anoe dalam hal mendistribusikan hasil produksi garamnya disalurkan pada dua distributor yaitu kepada UD Milhy dan para muge. Muge merupakan istilah yang diberikan dalam bahasa Aceh bagi orang yang berprofesi sebagai pembawa barang dari satu tempat ke tempat lain dalam wilayah Provinsi Aceh dengan menggunakan sepeda motor (khusus pembawa barang berupa garam disebut muge sira). Jaringan dengan UD Milhy Jaya dibangun melalui skema UD Milhy Jaya memberikan modal (bibit garam) kepada petani garam, kemudian hasil produksi dari petani garam akan didistribusikan ke UD Milhy Jaya. Sementara jaringan dengan para muge dibangun berdasarkan kepercayaan. Modal (bibit garam) dipesan langsung oleh petani kepada pemasok bibit garam, kemudian hasil produksi garam dibantu oleh para muge untuk dijual kepada konsumen. Inti permasalahan dalam penelitian ini adalah bagaimana jaringan sosial petani garam dibentuk dengan pihak-pihak yang mendistribusikan garam terutama dengan keberadaan UD Milhy Jaya di gampong tersebut. Lalu bagaimana jaringan sosial petani garam dibentuk dengan muge-muge yang mendistribusikan hasil produksi garam para petani. Penelitian ini berada dalam ranah kajian sosiologi ekonomi (Widhyharto, 2012).

Penelitian terdahulu yang digunakan untuk memperkuat topik yang akan diteliti diantaranya studi yang dilakukan oleh Amiruddin (2014). Berdasarkan hasil penelitian tentang jaringan distribusi ikan dipahami bahwa bagi nelayan yang memperoleh pemodalan untuk melaut melalui langgan (pemilik modal), maka pemasaran dan penentuan harga dikendalikan oleh langgan. Sedangkan nelayan yang tidak memiliki ikatan pada langgan, maka jaringan sosial pemasaran hasil tangkapan dilakukan secara langsung melalui TPI (Tempat Pelelangan Ikan) Lontar. Penelitian selanjutnya oleh Putra (2010) membahas mengenai hubungan sosial serta hubungan ekonomi masyarakat pengusaha makanan tradisional yang kaitannya dengan keberlangsungan usaha industri tempe. Dalam penelitian ini interaksi para pengusaha tempe bersifat kerjasama, kegotongroyongan, persahabatan, dan kesamaan dalam jaringan sosial sebagai sarana untuk mengembangkan usaha tempe.

\section{Teori Jaringan}

Teori yang digunakan untuk menganalisa penelitian ini adalah teori jaringan yang digagas oleh Marin \& Wellman (2011). Kedua sosiolog tersebut telah memberikan kontribusi untuk teori analisa jaringan sosial dengan penekanan pada jaringan individu. Analisis jaringan cenderung menggerakkan para sosiolog menjauh dari studi atas kelompok-kelompok sosial dan kategorikategori sosial. Analisis jaringan mengarahkan studi menuju ikatan-ikatan diantara para aktor yang 
tidak "terikat secara memadai dan terajut secara rapat untuk disebut kelompok". Adapun kaitan teori jaringan sosial dengan penelitian yang akan peneliti lakukan adalah dilihat pada aspek jaringan sosial petani garam dalam mendistribusikan hasil produksi garam. Adanya kontak sosial dan interaksi sejatinya tidak hanya terjadi antara dua belah pihak yang saling mengenal, melainkan tidak menutup kemungkinan terbentuknya hubungan yang lebih luas dengan orang-orang yang bahkan tidak dikenali (Purwanto, 2017).

Jaringan sosial merupakan jembatan dalam memudahkan urusan banyak pihak yang berkepentingan. Jaringan sosial bisa dianalisis baik di tingkatan individu maupun struktur sosial (Damsar \& Indriani, 2009). Jaringan sosial berbeda dengan kelompok karena keanggotaan jaringan sosial sering kali tidak disadari atau belum tentu disadari oleh individu yang bersangkutan (Agusyanto, 2007). Berdasarkan tinjauan hubungan sosial yang membentuk jaringan sosial dalam suatu masyarakat, jaringan sosial dapat dibedakan menjadi tiga jenis yaitu jaringan kekuasaan, jaringan kepentingan, dan jaringan perasaan (Fikriyah, 2017). Jaringan sosial sendiri merupakan salah satu dimensi sosial selain kepercayaan dan norma (Field, 2005). Jaringan sosial merupakan hubungan sosial yang diikat oleh adanya kepercayaan yang mana kepercayaan itu dipertahankan dan dijaga oleh norma-norma yang ada (Kasim, et al., 2021). Pada dasarnya jaringan sosial terbentuk karena adanya rasa saling mengetahui, saling menginformasikan, saling mengingatkan, dan saling membantu dalam melaksanakan ataupun mengatasi sesuatu (Lawang, 2005).

Dalam usaha untuk memperlancar arus barang dan jasa dari produsen dan konsumen, maka faktor penting yang tidak boleh diabaikan adalah distribusi. Distribusi merupakan saluran yang digunakan oleh produsen untuk menyalurkan barang dari produsen sampai ke konsumen atau pemakai industri (Sholihah, et al., 2017). Adapun fungsi distribusi yaitu dalam proses pengangkutan atau transportasi, penjualan, pembelian, penyimpanan, pembakuan standar kualitas barang, serta penanggung resiko (Rochwulaningsih, 2013). Distributor membantu dalam mengalihkan hak atas barang atau jasa berpindah dari produsen ke konsumen (Karundeng, et al., 2018). Berkaitan dengan pendistribusian garam di Gampong Tanoh Anoe, fungsi distribusi sangatlah beragam. Dalam hal ini, distribusi dimanfaatkan sebagai akses untuk menjual garam dari petani garam kepada masyarakat, baik menyalurkan garam kepada agen-agen yang sudah menjadi distributor dari masa ke masa maupun mendistribusikan hasil produksi garamnya langsung ke muge-muge yang sudah menjalin jaringan sosialnya.

Sektor pertanian garam di Gampong Tanoh Anoe mempunyai peran yang penting dalam memunuhi kebutuhan perekonomian masyarakat gampong tersebut, dan menjadi salah satu sektor unggulan bagi masyarakat di Gampong Tanoh Anoe. Di Gampong Tanoh Anoe petani garam 49 | Jurnal Ilmu Sosial dan Ilmu Politik Malikussaleh (JSPM) Volume 2 Nomor 1 Tahun 2021 
terbagi dua, yaitu petani yang memiliki modal dan petani yang tidak memiliki modal. Relasi yang terbangun diantara petani garam yang tidak memiliki modal sendiri dengan distributor (UD Milhy Jaya) adalah relasi patron-klien (Ketaren, 2015). Seperti halnya yang diungkapkan oleh Scott (1993), ada beberapa arus patron yang harus diterima klien, yaitu penghidupan subsistensi dasar, jaminan krisis subsistensi, perlindungan, makelar dan pengaruh, serta jasa patron kolektif. Sementara itu, arus klien (petani garam yang tidak memilki modal) ke patron (UD Milhy Jaya) yang disebutkan Scott (1993) ialah seseorang klien umumnya menyediakan tenaga dan keahliannya untuk kepentingan patron, apapun bentuknya. Unsur-unsur tipikal mencakup jasa pekerjaan dasar (biasanya pekerjaan pertanian), jasa tambahan (misalnya menyediakan air dan kayu bakar) bagi rumah tangga patron, jasa domestik pribadi, pemberian makanan secara periodik, dan biasanya berfungsi sebagai anggota setia dari faksi lokal sang patron.

\section{METODE PENELITIAN}

Lokasi penelitian adalah Gampong Tanoh Anoe yang terletak di Kecamatan Jangka Kabupaten Bireuen. Gampong Tanoh Anoe ini dijadikan sebagai lokasi penelitian karena sebagai sentral produksi garam yang mayoritas warganya bekerja sebagai petani garam atau menjadikan pekerjaan tersebut sebagai mata pencahariannya. Peneliti mendalami lebih lanjut mengenai distribusi garam petani dan jaringan sosial yang dibentuk oleh petani garam sehingga mampu menarik distributor untuk memasarkan garamnya. Metode yang peneliti gunakan dalam penelitian ini adalah metode kualitatif dengan hasil analisis berbentuk deskriptif dengan berusaha memahami dan menafsirkan makna sesuatu peristiwa interaksi tingkah laku manusia dalam situasi tertentu menurut perspektif peneliti sendiri (Usman \& Akbar, 2009). Terkait dengan informan penelitian pertama sekali memanfaatkan key person atau tokoh yang memahami objek penelitian untuk mulai menemukan data wawancara atau observasi (Bungin, 2007). Informan kunci adalah para ahli yang sangat memahami dan dapat memberikan penjelasan tentang berbagai hal yang berkaitan dengan penelitian (Mantra, 2004). Dalam hal ini, yang peneliti temukan satu informan kunci yaitu Sekretaris Desa (Sekdes). Selain itu, peneliti juga menggali data dari aktor-aktor yang terlibat dalam permasalahan yang hendak diteliti diantaranya Ketua UD Milhy Jaya, dua orang muge garam, dan 2 orang petani garam. Adapun teknik pengumpulan data antara lain:

1. Observasi Non-Partisipan

Alasan peneliti menggunakan teknik observasi non-partisipan adalah karena peneliti ingin mengamati langsung bagaimana perilaku dari informan dan memperoleh pengalaman langsung sehingga memudahkan peneliti dalam melakukan analisis data.

50 | Jurnal Ilmu Sosial dan Ilmu Politik Malikussaleh (JSPM) Volume 2 Nomor 1 Tahun 2021 
2. Wawancara

Alasan peneliti menggunakan teknik wawancara adalah untuk dapat mengetahui dan memahami realitas yang terjadi di lapangan. Kemudian dengan menggunakan teknik wawancara, peneliti dapat dapat menggali lebih dalam tentang data yang dibutuhkan sehingga makna yang terdapat di balik suatu kejadian tersebut dapat ditangkap.

3. Dokumentasi

Alasan peneliti menggunakan teknik dokumentasi adalah sebagai data pelengkap agar data hasil penelitian lebih kredibel dan terpercaya.

Penelitian ini menggunakan teknik analisis data kualitatif secara interaktif yang dikembangkan oleh Miles dan Haberman (dalam Sugiyono, 2013) dimana mereka menjelaskan langkah-langkah menganalisis data terdiri atas reduksi data, penyajian data, dan penarikan kesimpulan/verifikasi.

\section{HASIL DAN PEMBAHASAN}

\section{Sistem Produksi Garam di Gampong Tanoh Anoe}

Masyarakat Tanoh Anoe memproduksi garam secara turun temurun dengan proses perebusan air asin secara tradisional. Walaupun demikian, terdapat pergeseran dari awal mula proses perebusan garam dengan menggunakan tahapan hu anoe (menggarap tanah), tireeh ie (menyaring air), proem ie (penyimpanan air), dan yang terakhir baru taguen sira (perebusan). Tahapan perebusan itu hanya dilakukan oleh petani garam di tahun 1980-an sampai 1999. Kemudian sekitar tahun 2000-an proses pembuatan garam yang dilakukan masyarakat Gampong Tanoh Anoe bergeser dikarenakan masuknya bibit beli dari pemasok garam tersebut, sehingga masyarakat beralih pada proses pembuatan garam yang lebih praktis (Observasi, 10 Februari 2020). Berdasarkan hasil wawancara dengan salah satu petani garam diperoleh keterangan:

"Bak thoen 80-an sampek 90-an, nek-nek gata geu peugeut sira cukoep brat eh, seubab payah hu anoe, tireeh ie anoe, yang adeuh wate si uroe seupoet, baroe jeut geu cok ie nyan geu simpan, oeh leuh geu simpan ie simalam baroe jeut geu taguen sira, nyan pih bak geu taguen sira abeuh waktee meu 6 jeum. Kamoe nyoe petani sira jinoe leubeh mangat peuget sira ngeun bloe bibet manteng bak toke bibet, kareuna leubeh mudah bak ta peuget sira, hanya perle wate 3 atau 4 jeum ka masak sira."

(Pada tahun 80-an sampai 90-an, nenek moyang kita membuat garam sangatlah sulit, disebabkan harus melakukan proses menggarap tanah, menyaring air tanah, yang memerlukan waktu seharian untuk proses itu saja, kemudian air yang sudah disaring disimpan semalaman, baru kemudian bisa direbus air tersebut untuk dibuat garam yang proses perebusannya memerlukan waktu 6 jam. Petani garam sekarang lebih memilih proses pembuatan garam dengan menambahkan bibit garam, karena lebih menghemat

51 Jurnal Ilmu Sosial dan Ilmu Politik Malikussaleh (JSPM) Volume 2 Nomor 1 Tahun 2021 
waktu dalam proses pembuatan garam, waktu yang diperlukan hanya 3 atau 4 jam sudah menjadi garam yang bisa dikonsumsi) (Maryana, Gampong Tanoh Anoe, 10/02/2020).

Dari hasil wawancara bisa kita pahami bahwa masyarakat Gampong Tanoh Anoe yang bekerja sebagai petani garam sekarang lebih memilih proses tahapan pembuatan garam yang menambahkan bibit garam untuk direbus dikarenakan waktu perebusannya hanya 3-4 jam. Adapun tahapan pertama dalam pembuatan garam yaitu membuat dapu sira (tungku masak), air bibit garam, dan plat besi untuk dijadikan drom sira (tempat atau kuali) membuat garam dengan ukuran 2x3 meter, dan menggali meun sira (sumur) dekat dapur garam seluas 4x5 meter. Proses ini tidak perlu dilakukan setiap hari untuk pembuatan garam, karena proses ini bisa bertahan semi permanen sampai 5 atau 8 bulan.

Tahap selanjutnya yaitu menambahkan bibit garam ke dalam kuali yang telah diisikan air asin yang telah disimpan. Biasanya petani garam membeli bibit garam seharga Rp 80 ribu per karung dengan bobot $50 \mathrm{Kg}$. Dalam satu kali pembuatan garam, petani garam menambahkan 33 $\mathrm{Kg}$ bibit garam ke dalam kuali yang telah diisikan air.

Setelah ditambahkan bibit garam yang disertai dengan air asin tersebut, tahap selanjutnya adalah perebusan. Dalam perebusan ini suhu yang diperlukan agar kristal garam cepat terbentuk adalah $180^{\circ}$ C. Setelah setengah dari proses perebusan dilakukan, air dan bibit yang direbus sudah mendidih dengan mengeluarkan buih-buih yang kotor sehingga petani garam harus menyaring atau membuang buih-buih tersebut. Setelah buih-buih tersebut disaring atau dibuang petani garam menambahkan lagi air sebanyak 3 atau 4 ember kecil. Penambahan air ini dinamakan dengan suyong yang dilakukan untuk menambah kristal garam yang terbentuk. Adapun tahap proses perebusan garam masyarakat Tanoh Anoe dapat dilihat dari gambar berikut:

Tabel 1. Proses Pembuatan Garam di Gampong Tanoh Anoe

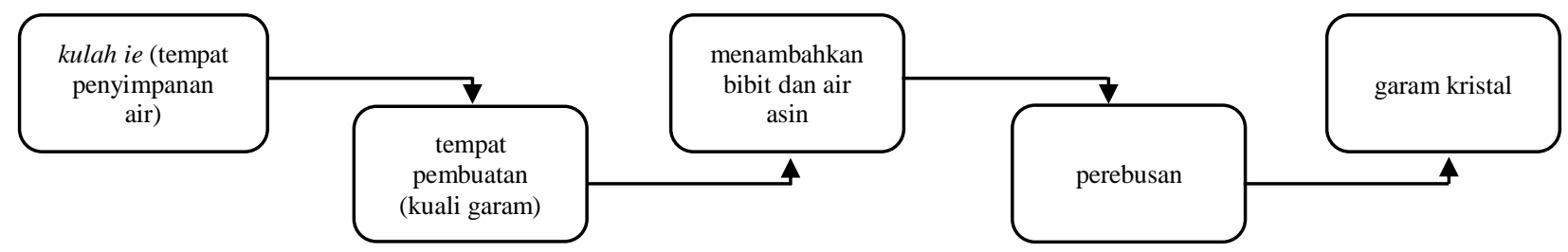

\section{Bentuk-Bentuk Jaringan Sosial Petani Garam dengan Distributor}

Terkait cara mendistribusikan hasil produksi garam, petani garam harus membangun jaringan sosial dengan distributor (Observasi, 05/03/2020). Distribusi merupakan kegiatan penyampaian produk sampai ke tangan konsumen pada waktu yang tepat (Assauri, 2013). Penyaluran itu sendiri harus memperhatikan beberapa hal, apakah penyaluran produk tersebut 
sesuai dengan ketahanan produk atau tidak. Misalkan produk tidak tahan lama, maka penyaluran produk menghindari saluran yang panjang, karena akan memakan banyak waktu penyalurannya. Di Gampong Tanoh Anoe sendiri produk yang didistribusikan adalah garam dengan ketahanan produk cukup lama, sehingga penyaluran produk garam di Gampong Tanoh Anoe bisa memakai saluran distribusi yang panjang.

Di Gampong Tanoh Anoe, dalam bentuk saluran distribusi garam ini para petani garamnya membutuhkan perantara seperti: muge garam, UD Milhy Jaya, dan masyarakat. Berikut ini adalah struktur distribusi yang dilakukan oleh petani garam dalam memasarkan produksi garamnya:

\section{a. Petani Garam - UD Milhy Jaya - Pengecer - Konsumen}

Petani garam dapat mendistribusikan hasil produksi garamnya kepada UD Milhy Jaya. Keberadaan UD di Gampong Tanoh Anoe tersebut sangat membantu petani garam yang kekurangan ekonomi. UD memberikan pinjaman modal bibit untuk dapat diproduksi oleh petani garam. Berikut hasil wawancara dengan salah satu informan:

"Kami petani garam yang meminjam bibit garam dari UD Milhy Jaya tidak bisa menjual garamnya kepada distributor lain. Karena pihak UD akan mengambil hasil produksi garam yang telah siap untuk didistribusikan”. (M. Nur, 06/03/2020).

Petani garam yang telah bekerjasama dengan UD Milhy Jaya tidak perlu memikirkan pendistribusian hasil produksinya. Dengan mekanisme rantai distribusi di atas, maka status petani garam yang meminjam bibit garam pada UD Milhy Jaya hanya diposisikan sebagai produsen pembuat garam, tanpa akses pasar sama sekali. Pemilik modal seperti UD memiliki kesempatan untuk menguasai produk garam yang dihasilkan petani dan sekaligus menguasai akses pasar. Dalam kondisi yang demikian, terbuka peluang luas bagi UD Milhy Jaya untuk menentukan harga garam secara sepihak (Observasi, 05/03/2020). Kemudian UD Milhy Jaya membangun kerjasama dengan pihak-pihak supermarket atau mall dan pasar-pasar besar untuk distribusi garam tersebut (Observasi, 11/02/2020).

Jejaring, tentu tidak terbentuk begitu saja. Sebelumnya sudah terlebih dahulu ada unsurunsur yang dapat memicu tumbuhnya jejaring. Pada awal mula terbentuk suatu hubungan yang terkait resiprositas ini, interaksilah yang menjadi penyambung awal sehingga membentuk jaringan. Dalam konteks ekonomi, simpul-simpul pertama kali dibuat ketika satu pihak berinteraksi dengan pihak lain. Oleh karena adanya berbagai hubungan, kerjasama pun akhirnya diciptakan (Damsar \& Indrayani, 2009). 
Interaksi yang dilakukan berbagai pihak akan menimbulkan terbentuknya jaringan sosial yang terikat hubungan kerja secara ekonomi. Khususnya dalam kasus petani garam, jaringan terbentuk juga demikian adanya. Meskipun pertama kali petani garam berinteraksi tidak langsung untuk menjalin relasi kerjasama, pada akhirnya faktor ekonomi mendorong kuat untuk membentuk jaringan, maka jaringan sosial pun terbentuk. Oleh karena kekurangan faktor ekonomi yang mendukung, petani garam yang bekerjasama dengan UD Milhy Jaya, mau tidak mau harus meminta modal bibit kepada UD Milhy Jaya untuk dapat memproduksi garam. Dalam peminjaman modal bibit garam pada UD Milhy Jaya itu, tidak semata-mata terbentuk begitu saja melainkan ada ikatan-ikatan atau perjanjian-perjanjian kerjasama yang mereka jalin. Perjanjian memang tidak tertulis. Pola kerjasama masyarakat gampong itu diikat dengan kepercayaan satu sama lain. (Observasi 11/02/2020).

Dari hasil observasi dan wawancara penulis menemukan bahwa pihak UD Milhy Jaya membuat perjanjian dengan petani garam dengan ketentuan: 1) Hasil produksi garamnya tidak boleh dijual kepada distributor lain selain pihak UD Milhy Jaya, 2) Petani Garam harus memproduksi dan menjaga stok garam sesuai keperluan UD Milhy Jaya, dan 3) Petani garam harus memperhatikan kualitas garam yang mereka produksi. Informan penelitian menyampaikan:

"Kami yang bekerja sebagai petani garam yang tidak mempunyai modal bibit sendiri akan bekerjasama dengan UD Milhy Jaya dengan perjanjian yang harus kami patuhi dan taati... Dengan perjanjian itu kami taati maka akan selalu pihak UD memberikan modal bibit garam kepada kami”. (Wawancara, 07/03/2020).

Sebagai bagian dari masyarakat petani garam, peran UD Milhy Jaya tentu menjadi bagian yang sangat dibutuhkan dalam keberlangsungan hidup serta kesejahteraan petani garam itu sendiri. Modal berupa tersedianya bibit garam menjadi pokok utama yang sudah menjadi kewajiban bagi setiap petani garam yang kekurangan faktor ekonomi dalam membeli bibit garam sendiri (Observasi, 11/02/2020).

Upaya peminjaman modal untuk melakukan aktivitas produksi garam itu dilakukan oleh karena petani garam yang berada di Gampong Tanoh Anoe merupakan masyarakat yang tingkat ekonominya lemah. Untuk itu mereka harus pintar mensiasati cara mendapatkan modal memproduksi garam dari UD Milhy Jaya. Bentuk siasat yang dilakukan oleh petani garam yaitu bertemu langsung dengan Ketua UD Milhy Jaya. Mereka menceritakan keinginan untuk bisa bekerjasama dengan pihak UD agar bisa memenuhi kebutuhan hidup sehari-hari. Maka, untuk memperoleh modal bibit garam dari UD tersebut, perlu tercipta hubungan yang baik dengan pihak UD. Hubungan yang baik yang diciptakan oleh petani garam ialah hubungan yang jujur, baik itu 
dalam hubungan kerja maupun pembentukan jaringan sosial diantara keduanya. Berikut hasil wawancara dengan petani garam yang bekerjasama dengan UD Milhy Jaya yang bernama M. Nur yang bertindak sebagai informan penelitian:

"Dalam bekerjasama dengan pihak UD Milhy Jaya, Kami sangat dianjurkan untuk berperilaku jujur, baik dalam bekerja. Dengan demikian kami akan selalu dipercayai oleh pihak UD untuk bisa tetap bekerjasama dengannya". (Wawancara, 06/03/2020).

Pembentukan jaringan sosial antara petani garam dengan UD Milhy Jaya pada awalnya ditandai dengan adanya upaya peminjaman modal oleh petani garam kepada UD guna melancarkan aktifitas produksi garam. Modal yang dimaksud adalah berupa bibit garam yang merupakan bahan utama dalam hal memproduksi garam (Observasi, 12/02/2020). Peminjaman modal ini merupakan bagian dari hubungan yang dibangun oleh petani garam yang kemudian memungkinkan terciptanya jaringan sosial yang kuat yang selanjutnya akan meluas ke jejaring-jejaring lainnya. Dalam hubungan yang diciptakan oleh petani garam itu bermula mereka menceritakan kesulitan kepada pihak UD yang dibarengi terbentuknya hubungan kerjasama secara ekonomi sehingga akhirnya jaringan sosial pun terbentuk.

Jaringan sosial diakui petani garam yang berada di Gampong Tanoh Anoe merupakan hal yang sangat penting yang harus dimiliki dan ditata dengan baik oleh kedua belah pihak, meskipun petani garam yang kekurangan ekonomi ini lebih cenderung terlihat membutuhkan bantuan dari UD Milhy Jaya. Satu hal yang juga diungkapkan oleh informan petani garam:

"Awalnya hubungan ini terjadi biasa saja, hanya sekedar hubungan kerja petani garam dan pihak UD, namun lama kelamaan hal ini menjadi bagian dari kehidupan sosial kami, tidak ada yang mengganjal diantara kami, sehingga rasa-rasanya hubungan kami ini layaknya seperti saudara, sama-sama saling membantu, saling menginformasikan segala sesuatu yang berkaitan dengan kehidupan kami sampai saat ini”. (M. Nur, 12/02/2020).

Jaringan sosial dijelaskan terbentuk atas dasar adanya kesepakatan dan kesepahaman kerja antara kedua belah pihak terkait. Setelah membentuk hubungan kerja yang baik, naluri kemanusiaan untuk saling membantu dan saling memberi diantara keduanya pun muncul. Berikut hasil wawancara dengan Ketua UD Milhy Jaya memodali bibit garam kepada petani:

"Saya selaku Ketua UD Milhy Jaya, sangat menguntungkan dengan adanya kerjasama dengan petani garam yang mau kami modali, karena kami pihak UD hanya memikirkan cara untuk mendistribusikannya saja. Masalah produksi kan sudah ada petani garam tersebut. Kami pihak UD hanya membayar kepada petani tersebut harga bersihnya saja. Biasanya kami membayar dengan harga 50 ribu per karung garamnya". (Wawancara, 13/02/2020). 
Dari segi pembatasan akses menjual garam memperlihatkan bahwa ada hubungan antara petani dengan pihak UD yang terjadi hubungan yang eksploitatif. Seperti yang dikatakan Mirajiani (2014) bahwa hubungan tersebut ada arus pertukaran timbal balik namun tidak menjamin satu pihak mendapatkan imbalan yang setimpal dengan pihak lain. Adakalanya yang terjadi justru eksploitasi satu pihak yang menguasi sumber daya lebih banyak terhadap pihak yang memiliki nihil atau sedikit sumber daya. Dari proses produksi dan pascaproduksi, semua kegiatan bertani diatur oleh pihak UD. Petani menuruti semua perintah pihak UD karena mereka yang memberi modal untuk dapat memproduksi garam. Dari hasil observasi dan wawancara dengan ketua UD Milhy Jaya, pada saat sekarang ini pihak UD mempunyai 15 petani garam yang bekerjasama dengan UD.

Dalam memasarkan hasil produksi garam pihak UD membangun jaringan dengan wilayah lain. Berikut penulis mewawancarai Ketua UD Milhy Jaya yang bernama Qurata Aini mengatakan bahwa:

"UD Milhy Jaya sudah dikenal pada kalangan masyarakat Bireuen, maka dengan itu kami membangun jaringan yang lebih luas lagi, kami sering memasarkan garam sampai ke wilayah lain seperti Langsa, Takengon, Banda Aceh, Meulaboh. Cara kami memasarkannya itu lebih ke area supermarket, minimarket, pasar-pasar yang ada di wilayah kota-kota itu. Kami tidak memasarkan langsung ke konsumen akhir". (Wawancara 07/03/2020).

Bentuk transaksi jual beli yang dilakukan pihak UD dengan pihak-pihak yang memasarkan garamnya dengan transaksi lewat rekening. Pihak UD akan menerima hasil jualan garamnya seminggu setelah mereka mengantarkan garam ke pihak-pihak yang memasarkan garamnya. Itu sudah kesepakatan antara kedua belah pihak, dan sudah berlangsung lama dimana hampir 8 tahun mereka membangun kerjasama seperti ini.

Pemberian modal bagi petani oleh pihak UD sangat membantu proses produksi garam. Bagi petani garam, kayu bakar dan wadah memasak merupakan elemen yang sangat penting untuk memasak garam. Petani sering dihadapkan sulitnya membeli kayu bakar dan wadah memasak karena biayanya yang mahal. Ketiadaan kayu bakar dan wadah memasak yang baru (karena wadah memasak yang lama tidak dapat digunakan lagi) berimplikasi produksi garam yang dihasilkan. Petani tidak mampu mengeluarkan biaya sebesar Rp. 300.000 untuk membeli kayu bakar (kayu tersebut mampu memasak garam 4-7 kali, tergantung tingkat kekeringan dan tipe kayu). Biasanya kayu bakar tersebut diantar menggunakan mobil L300 pick-up ke pondok garam petani.

Perlindungan yang UD Milhy Jaya berikan kepada petani yang tidak memiliki modal sendiri disikapi sebagai hal yang positif oleh petani. Pihak UD memiliki kepentingan memberikan pinjaman kayu kabar, membuat wadah memasak, dan bibit garam terhadap petani untuk memperkuat hubungan diantara mereka dan meyakinkan petani bahwa UD Milhy Jaya benar-benar 
mampu melindungi petani garam dalam kondisi terjepit. Hal ini membuat petani garam semakin nyaman bekerjasama dengan UD Milhy Jaya yang menjadi tuannya.

Tabel 2. Pola Pemasaran Garam Petani yang tidak Memiliki Modal

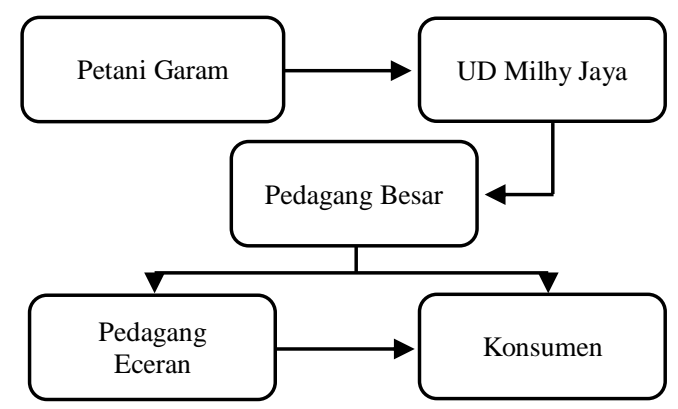

\section{b. Petani Garam - Muge Garam - Konsumen}

Kepemilikan modal memberikan pilihan petani garam dalam melakukan pemasaran garam. Petani bebas menentukan pembeli garam disebabkan modal dari produksi berasal dari petani sendiri. Petani garam dapat menjual garamnya kepada muge garam, pedagang eceran, dan konsumen (Observasi, 07/03/2020). Petani garam yang menjual garamnya kepada muge tidak perlu memikirkan biaya transportasi untuk mengantarkan garam kepada muge, karena muge garam datang langsung ke pondok garam. Biasanya petani garam menjual garamnya kepada muge dengan harga yang lebih rendah. Seperti pengakuan yang diungkapkan oleh informan berikut:

"Petani garam seperti kami ini bisa menentukan harga garam yang kami jual sesuai pasaran, kami menentukan harganya jika harga bibit garam seperti yang dibeli sekarang mencapai 80 ribu per karungnya, maka akan kami jual hasil produksi garam Rp.3.800- Rp.4.000/kg musim hujan, Rp.3.700-Rp.3.800/kg musim kemarau” (Maryana, 06/03/2020).

Meskipun petani garam yang menentukan harga garamnya tersebut, tetapi petani garam dan muge garam itu dalam suatu jaringan yang masing-masing pihak harus selalu mengakui dan memperhitungkan untung rugi, dan bahkan di antara mereka saling berkomunikasi jika dipandang perlu dalam menentukan harga yang sewajarnya (Observasi, 06/03/2020). Keuntungan membangun jaringan dengan muge garam ialah petani mendapatkan jaminan penjualan garam yang dilakukan setiap hari, sementara keuntungan muge membangun jaringan dengan petani akan mudah mendapatkan barang yang diinginkan (Dewi, 2017).

Muge tidak pergi begitu saja dari pondok petani setelah membeli garam. Mereka meluangkan waktu untuk berbincang-bincang/mengobrol santai dengan petani garam. Terlihat bahwa bukan semata-mata keuntungan finansial saja yang terjalin, akan tetapi hubungan sosial antara petani dan muge berjalan secara intens. Atas dasar kepercayaan, jalinan kemitraan antara 
petani dan pedagang perantara berlangsung seperti yang diharapkan. Hubungan kerjasama terlihat cukup seimbang dan petani menganggap ikatan seperti ini merupakan ikatan yang baik dan tidak memberikan kerugian bagi mereka (Observasi, 06/03/2020).

Bagi masyarakat biasa yang berada di Gampong Tanoh Anoe yang tidak berprofesi sebagai petani garam biasanya langsung membeli garam di pondok garam. Petani garam (yang mempunyai modal sendiri) pada umumya juga menjual garam kepada masyarakat yang membeli eceran berdasarkan wawancara berikut:

"Kami juga ada menjual garam ke masyarakat yang datang langsung ke pondok garam kami. Harga yang kami jual memang agak lebih tinggi daripada harga muge, biasanya harga yang kami jual Rp.4.500-Rp.5.000/Kg. Tetapi kami juga sedikit melebihkan takaran garam yang kami jual kepada konsumen tersebut.” (Maryana, 05/03/2020).

Jaringan sosial, terlepas dari tinjauan sosialnya, juga sangat berkaitan dengan petani garam dan hubungannya dengan distributor dalam konteks ekonomi. Jaringan sosial merupakan kunci penting dalam menciptakan relasi yang baik, khususnya relasi kerjasama. Pada dasarnya keinginan untuk membentuk jejaring dimulai dari adanya rasa saling membutuhkan antara petani garam dengan distributor. Petani garam sebagai pihak yang tidak memiliki relasi dalam mendistribusikan hasil produksi garamnya membangun kerjasama dengan pihak distributor agar dapat mendistribusikan garam. Sama halnya dengan petani garam, pihak distributor pun membentuk jaringan dengan petani garam karena ada kepentingannya sendiri. Dalam hal ini, distributor akan lebih mudah mendapatkan garam dan bisa menjual garam tersebut dengan penawaran bertingkat (Observasi, 11/02/2020).

Muge merupakan bagian dari jaringan sosial petani garam dalam mendistribusikan hasil produksi garam. Garam yang sudah diproduksi oleh petani akan dibeli oleh muge untuk kemudian dijual kembali dengan cara membawa garam keliling atau dijual di pekan-pekan harian pelosok gampong (Observasi, 13/02/2020). Selain itu, muge dalam hal ini juga memiliki ikatan dengan berbagai kelompok yang ada dalam jaringan sosial petani garam. Bisa dikatakan, sebagian besar muge yang mengambil garam pada petani sudah mengenal baik atau bahkan membentuk jejaring dan membina hubungan kerjasama secara terbuka.

Muge-muge yang telah membangun jaringan sosial dengan petani garam akan mudah dalam mendapatkan garam dengan harga yang sudah disesuaikan. Mengenai bagaimana bentuk jaringan tersebut, seorang muge yang bernama $\mathrm{H}$. Ilyas yang bertindak sebagai informan telah mengemukakan penjelasan mengenai hal tersebut:

"Menjadi bagian dari distributor garam itu juga tidak mudah seperti yang kita bayangkan. Akan tetapi, di Gampong Tanoh Anoe umumnya bekerja sebagai petani garam, kami 
melihat peluang menjadi distributor garam sangatlah besar, karena itu kami sebagai muge akan membangun jaringan dengan para petani, dalam hal untuk memudahkan memperoleh garam. Kami muge-muge garam yang telah membangun hubungan yang baik dengan para petani garam hanya datang ke tempat pembuatan garam untuk mengambil garam yang sudah siap kami distribusi, biasanya kami mendistribusikan di hari-hari pekan harian yang ada di kecamatan, di gampong-gampong”. (Wawancara, 13/02/2020).

Jaringan itu dijalin agar memudahkan muge mendapatkan garam dan juga muge dengan mudah memperoleh keuntungan dengan mendapatkan bagian garam dengan cepat, sehingga tidak harus menunggu waktu lama dan tentunya dengan memperoleh garam yang lebih praktis. Lalu bagaimana muge menerapkan pola kerja dengan petani garam untuk memudahkan memperoleh garam? Berikut hasil wawancara dengan muge yang bernama Muzakkir yang bertindak sebagai informan penelitian:

"Garam yang sudah diproduksi oleh petani garam dan juga yang sudah dikemas oleh petani garam akan kami beli seharga 160 ribu per karung atau biasanya ada juga per kilonya seharga 4 ribu. Kami muge garam akan memberikan atau membayar uang petani garam setelah kami selesai menjual garamnya ke konsumen. Alhamdulillah sejak kami ada hubungan baik dengan petani garam transaksi semacam itu tidak menjadi kendala, dikarenakan kami sudah dipercayai oleh petani garam". (Wawancara, 13/02/2020).

Hasil wawancara di atas menunjukkan bahwa muge yang telah membangun jaringan dengan petani garam akan membayar hasil garam petani setelah muge selesai mendistribusikan kepada konsumen. Bentuk jaringan yang dibangun ialah saling mempercayai kedua belah pihak. Sejauh ini petani garam tidak pernah dikecewakan muge, karena muge-muge selalu menjaga kesepakatan bahwa selesai pendistribusian garam langsung muge membayar uang petani garam.

Berbicara tentang aktivitas distribusi garam yang ada di Gampong Tanoh Anoe, muge yang telah menjadi bagian dari jaringan sosial petani garam terus membina hubungan baik dengan petani garam itu sendiri. Jaringan yang dipergunakan untuk memperoleh hasil produksi garam ini pada dasarnya ialah kepercayaan satu sama lain. Dari hasil wawancara dengan Munirwan Usman, Sekretaris Gampong Tanoh Anoe menjelaskan bahwa:

"Masyarakat Gampong Tanoh Anoe yang pekerjaannya sebagai petani garam, pada umumnya mereka mendistribusikan hasil produksi garamnya pada muge-muge garam yang ada di Gampong Tanoh Anoe ini... menurut informasi yang saya dapatkan, mereka sudah lama membangun jaringan dalam hal mendistribusikan garamnya, dan tidak pernah ada konflik antara mereka, karena jaringan yang mereka bangun sudah ada rasa kepercayaan antara mereka keduanya". (Wawancara, 20/02/2020).

Bapak Muzakkir, salah satu muge garam yang ada di Gampong Tanoh Anoe menjelaskan bahwa: 
"Saya dengan salah satu petani garam yang saya distribusikan garam petani tersebut sudah sejak tahun 2010 sampai sekarang saya masih menditribusikan garam petani itu. Dari tahun 2010, saya mendistribusi garam sampai sekarang ini, saya tidak berpindah-pindah pada petani lain, karena hubungan kami sudah sangat baik, dan garamnya selalu disediakan untuk saya". (Wawancara, 13/02/2020).

Dari hasil wawancara diatas dapat kita pahami bahwa, petani garam yang sudah membangun hubungan baik dengan distributor atau muge harus selalu menyediakan garam untuk тияе-тияе garamnya. Muge akan senantiasa menetap pada petani garam yang menyediakan garam untuk muge distribusikan. Terkait hal ini, beberapa hasil wawancara dengan informan baik mengenai jaringan sosial dengan UD Milhy Jaya maupun muge-muge garam dapat kita pahami bahwa jaringan sosial petani garam di Gampong Tanoh Anoe memang sudah lama terbentuk. Terlihat jelas bahwa petani garam sebagai subjek dalam penelitian ini membina hubungan baik dalam artian menjaring kerjasama dengan pihak-pihak yang bisa membantu mereka untuk mendistribusi garam yang sudah diproduksi.

Tabel 3. Pola Pemasaran Garam Petani yang Memiliki Modal

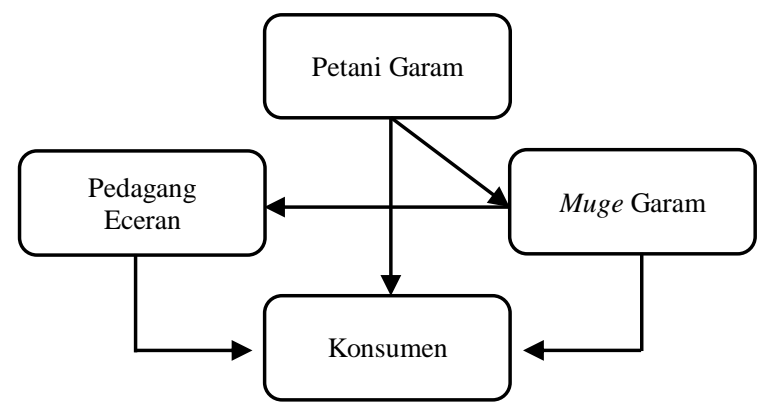

\section{Mempertahankan Jaringan Sosial}

Dalam konteks jaringan sosial, berhubungan baik saja dengan berbagai kalangan dalam masyarakat belum dikatakan suatu ikatan, jika tidak adanya kepercayaan yang timbul antar sesama dan saling membentuk resiprositas. Resiprositas dalam hal ini berkaitan erat dengan upaya saling memberi dan saling merespon satu sama lain (Damsar \& Indrayani, 2009). Sejalan dengan hal itu, petani garam yang berada di Gampong Tanoh Anoe dalam melakukan aktivitas kesehariannya juga berupaya membentuk jaringan. Jaringan ini dalam ikatan kepercayaan diciptakan agar dapat membantu melakukan semua proses yang bermanfaat bagi kehidupan mereka, tidak terkecuali dalam segi ekonomi. Dengan adanya hubungan kerjasama yang baik, segala sesuatu yang yang berkaitan dengan ekonomi akan berjalan dengan mudah.

Jaringan sosial ini dibentuk agar mempermudah akses dan jalannya distribusi yang dilakukan. Adanya transparansi dari pihak-pihak yang terlibat menumbuhkan rasa percaya dari 
para petani garam dalam melakukan kegiatan-kegiatan yang berhubungan dengan mata pencaharian ini. Transparansi yang dilakukan oleh pihak distributor ini menjadikan petani garam terus mempertahankan hubungan kerjanya. Akan tetapi, mempertahankan jaringan sosial yang telah lama dibentuk nyatanya lebih sulit daripada membentuk jaringan sosial itu sendiri. Butuh loyalti dan kerja keras dalam mencapainya. Dalam kasus petani garam di Gampong Tanoh Anoe, mempertahankan jaringan sosial dengan para distributor garam juga dilakukan dengan cara menjaga solidaritas petani garam (Observasi, 10/02/2020).

Untuk membina jaringan sosial antara petani garam dan para distributor haruslah didukung oleh aspek-aspek yang sangat krusial yang dinilai mampu memberikan kontribusi bagi pertahanan jaringan sosial sehingga tetap kuat dan solid, sehingga aspek-aspek tersebut dapat dijadikan sebagai konsep cikal bakal terciptanya hubungan sosial yang mampu dipertahankan dengan baik pula (Fikriyah, 2010). Adapun upaya mempertahankan hubungan kerjasama jaringan sosial petani garam dalam mendistribusikan hasil produksi garam diantaranya membangun kepercayaan (trust). Salah satu petani garam yang bertindak sebagai informan dalam penelitian ini mengemukakan mengenai kepercayaan strategik petani garam dalam menunjang aktivitas produksi garam:

"Saya sangat yakin sama muge garam yang mengambil garam yang sudah saya produksi. Muge garam tersebut selalu membayar uang garam saya setelah mereka habis menjual garam itu. Ada juga sesekali muge yang tidak habis laku garamnya, terpaksa tidak membayar terus uang garam saya, maka saya harus menunggu sampai garam yang muge didistribusi tersebut laku terjual". (Wawancara, 12/02/2020).

Selain kepercayaan atas kinerja serta transparansi yang ditunjukkan oleh para distributor dalam mendistribusikan hasil produksi garam petani, terdapat beberapa faktor lainnya yang mempengaruhi kepercayaan petani garam dalam jaringan sosial ini. Faktor lainnya itu adalah faktor ekonomi yang tidak lepas dari keseharian masyarakat. Segala sesuatu yang dilakukan masyarakat rasional tentunya berlandaskan pada keuntungan materil. Kalkulasi untung rugi selalu menjadi tolak ukur utama dalam melakukan kegiatan sehari-hari. Tidak jauh berbeda dengan petani garam yang berada di Gampong Tanoh Anoe yang menaruh kepercayaan pada orang-orang yang kelas ekonominya lebih tinggi dari mereka. Faktor ekonomi inilah yang menjadi penunjang kepercayaan seseorang terhadap pemilik ekonomi kelas tinggi. Untuk memperkuat keterangan di atas, peneliti telah melakukan wawancara dengan informan mengenai hal tersebut. Berikut hasil wawancaranya:

"Dimana-mana memang orang miskin seperti kami ini mau tidak mau harus bekerja, alhamdulillah di Gampong Tanoh Anoe ini ada UD yang mau memodalkan bibit garam untuk bisa kami produksi. Akan tetapi, rasa sosial yang ada pada pihak-pihak UD sangatlah tinggi. Kami tidak hanya dimodali bibit garam saja, juga dibantu hal-hal yang lain, semisalnya ketika kami membutuhkan uang tiba-tiba untuk berobat, selalu diberikan. Kalau

61 | Jurnal Ilmu Sosial dan Ilmu Politik Malikussaleh (JSPM) Volume 2 Nomor 1 Tahun 2021 
misalnya ada kelebihan darinya, kami juga selalu dipanggil untuk diberikan apa saja yang mudah yang dimilikinya. Jadi, kami yakin saja bahwa memang pihak UD tersebut selain dalam hubungan kerja, juga memiliki rasa empati yang tinggi”. (Wawancara 15/02/2020).

Kepercayaan itu mengundang loyalitas petani garam untuk tetap memproduksi garam UD Milhy Jaya pada pihak UD yang sama hingga menciptakan jaringan sosial yang kuat diantara keduanya. Berikut pengakuan salah satu petani garam mengenai rasa percaya mereka terhadap pihak UD atau pemilik modal bibit garam dalam segi ekonomi:

"Intinya seperti ini, karena adanya UD yang memiliki modal bibit garam maka lapangan pekerjaan kami pun mudah. Kalau mengharapkan lapangan pekerjaan dari pemerintahan itu mustahil, yang dibuat pemerintah hanya lapangan bola, bukan lapangan pekerjaan untuk kaum kelas bawah seperti kami. Pihak UD yang sangat membantu kami dalam mendapatkan pekerjaan, khususnya memproduksi garam. Pihak UD selain memberikan modal bibit garam, mereka juga akan mendistribusikan garam yang sudah diproduksi oleh petani garam, dan karena itulah kami mempercayai mereka". (Wawancara, 19/02/2020).

Rangkuman hasil wawancara peneliti dengan Sekretaris Gampong Tanoh Anoe diperoleh pemahaman:

"Petani garam dan UD itu sebernarnya sama-sama saling membutuhkan, saling membantu. Ketika petani garam mempercayai pihak UD untuk dimintai modal bibit garam, maka sudah ada aturan yang berlaku yang mendasari lahirnya kepercayaan. Hal itu ialah hasil penjualannya, benefit yang nyata. Kenapa pihak UD berani memberi modal banyak kepada petani garam, alasan kuatnya ialah setelah produksi garam sudah siap diproduksi, maka pihak UD mendistribusikan oleh UD itu juga, dan hasil penjualan seutuhnya dipegang oleh UD, baru kemudian petani garam mendapatkan jatahnya". (Wawancara, 16/02/2020).

Upaya petani berikutnya ialah meningkatkan produktivitas. Produktivitas merupakan ukuran efisiensi dari para pekerja (Sukirno, 2004). Dalam usaha pertanian produktivitas sangat berpengaruh terhadap keuntungan atau pendapatan. Dalam artian jika usaha produksi berjalan lancar usahanya akan berproduktif dan barang yang dihasilkan dapat diterima masyarakat. Hal ini akan memudahkan para petani garam menghasilkan profit yang besar. Ini menandakan bahwa meningkatnya produktivitas pertanian akan berdampak pada meningkatnya kualitas kehidupan dan kesejahteraan. Sama halnya dengan petani garam yang ada di Gampong Tanoh Anoe, dalam upaya mempertahankan jaringan sosial dengan para distributornya, harus meningkatkan produktivitas garamnya, seperti yang diungkapkan salah satu petani garam:

"Saya dalam sehari biasanya memproduksi garam hanya $120 \mathrm{Kg}$ saja, tetapi pada waktuwaktu tertentu yang memang garam sangat laris terjual, saya harus meningkatkan produksi garam, karena muge-muge garam yang mengambil garam hasil produksi saya meminta garam yang banyak... pada saat garam laris terjual maka muge garam biasa tiga hari sekali meminta $500 \mathrm{Kg}$ garamnya”. (Maryana, 13/02/2020). 
Petani garam pada waktu garam laris terjual rela pergi ke pondok garamnya dari jam 06.30 sampai 21.00 malam. Mereka harus bisa menyiapkan garam dalam sehari $200 \mathrm{Kg}$ garam, agar para distributor garam pada saat mendistibusikan garam akan selalu tersedia.

Meningkatkan kualitas garam juga menjadi salah satu strategi petani dalam mempertahankan jaringan distribusi garam. Berkaitan dengan hal ini, informan menyatakan bahwa ada beberapa hal yang harus dijaga dalam produksi agar garamnya bermutu. Berikut hasil wawancaranya:

"Dalam memproduksi garam, kami harus dengan sangat memperhatikan kualitas garam, supaya garam yang kami produksi bermutu, kami harus membersihkan dengan betul buihbuih kotoran garam yang ada pada proses produksi garam, sehingga setelah garam siap diproduksi akan kelihatan putih bersih garam tersebut”. (Wawancara, 16/02/2020).

Selain pengakuan di atas, informan lainnya yaitu salah satu muge garam yang bertindak sebagai informan pokok dalam penelitian juga mengungkapkan mengenai kualitas garam yang sesuai dengan standar kepuasan konsumen:

"Kami yang pekerjaan sebagai pendistribusian garam, harus memberitahukan pada petani garam agar tetap meningkatkan kualitas garamnya, agar dengan mudah terjual pada saat kami mendistribusikannya, karena memang kami perhatikan bahwa konsumen sering meminta garam yang putih bersih, sehingga kami muge-muge garam harus kasih info pada petani garam mengenai hal tersebut". (Wawancara, 18/02/2020).

Dalam meningkatkan kualitas garam petani garam juga perlu memerhatikan takaran berat garam itu. Menurut informan:

“Agar garam yang kami produksi mudah laku dan disukai oleh distributor... kami perlu memerhatikan berat garam yang kami produksi, kami perlu menambahkan air suyong... Kegunaan air suyong itu agar dapat menambahkan berat isi garam yang kami produksi”. (Maryana, 08/03/2020).

Upaya mempertahankan jaringan sosial petani garam selanjutnya yaitu penentuan harga. Dalam melakukan traksaksi jual beli pastinya terdapat negosiasi mengenai harga barang tersebut. Peranan harga dalam ekonomi pasar adalah untuk mengalokasikan sumber daya sesuai dengan permintaan dan penawaran. Penepatan suatu harga penjualan mempengaruhi pendapatan total dan biaya total, maka keputusan dan strategi penepatan harga memegang peranan penting dalam suatu perusahaan atau usaha apapun (Effendi, 2009). Berdasarkan hasil wawancara ditemukan bahwa para distributor dengan petani garam sering melakukan negosiasi harga garam, biasanya istilah "harga teman" digunakan antara petani garam dan distributornya. Informan menuturkan:

"Yang penting saya sudah mendapatkan keuntungan sedikit sudah cukup, karena dengan saya mendapatkan keuntungan sedikit itu, muge garam saya selalu mendistribusikan garam 
saya, tidak pernah muge garam saya itu protes dengan harga yang saya tentukan itu”. (Maryana, 18/02/2020).

\section{KESIMPULAN}

Bentuk-bentuk jaringan sosial petani garam dalam mendistribusikan hasil produksi garam, ditemukan bahwa: 1) Hubungan antara petani garam dengan UD Milhy Jaya: terbentuk akibat terjadinya upaya pemberian modal bibit garam oleh UD kepada petani garam untuk diproduksi, kemudian hasil produksinya diambil kembali oleh UD untuk didistribusikan, hasil pendistribusiannya akan dibagi kepada petani garam setelah pemotongan harga bibit garam UD itu. 2) Hubungan petani garam dengan muge garam, terbentuk akibat keadaan saling membutuhkan, saling menguntungkan (petani garam tidak ada skill dalam hal pendistribusian garam, sama halnya muge garam tidak skill untuk memproduksi garam) sehingga mereka membangun bentuk jaringan sosial antara keduanya, hasil pendistribusian garam tersebut akan diberikan kepada petani garam setelah muge selesai mendistribusikan garam itu.

Cara petani garam dalam mempertahankan jaringan sosial yang sudah ada, dilakukan melalui: 1) kepercayaan, 2) meningkatkan produktivitas, 3) meningkatkan kualitas garam, dan 4) penentuan harga secara standar. Meninjau ada berbagai dinamika yang terjadi dalam pembentukan jaringan sosial, maka khususnya dalam jaringan sosial petani garam tentu ada ikatan-ikatan yang berupa simpul dalam jaringan yang menghubungkan banyak pihak. Jika jaringan dimulai dari simpul yang pertama yaitu petani garam, dan sebelumnya terkoneksi dengan muge garam dan UD Milhy Jaya, maka kemudian akan mengundang pihak lain yang sebelumnya tidak tergabung, akan terhubung dalam lingkaran jaringan. Pihak yang pada awalnya tidak memiliki kepentingan, dengan adanya jaringan akan memiliki kepentingan yang kemudian akan membawa kepada penambahan ikatan simpul.

\section{DAFTAR PUSTAKA}

Agusyanto, R. (2007). Jaringan Sosial dalam Organisasi. PT. RajaGrafindo Persada.

Amiruddin, S. (2014). Jaringan Sosial Pemasaran pada Komunitas Nelayan Tradisional Banten. Komunitas: International Journal of Indonesian Society and Culture, 6(1), 106-115.

Badan Pusat Statistik Republik Indonesia (2014). Data Kebutuhan dan Produksi Garam Nasional 2004-2013.

Bungin, B. (2007). Penelitian Kualitatif. Kencana Prenada Media Group.

Damsar \& Indrayani (2013). Pengantar Sosiologi Ekonomi. Kencana Prenada Media Group.

64 | Jurnal Ilmu Sosial dan Ilmu Politik Malikussaleh (JSPM) Volume 2 Nomor 1 Tahun 2021 
Departemen Perindustrian Republik Indonesia (2009). Peta Panduan Pengembangan Klaster Industri-Industri Prioritas, Industri Kecil dan Menengah Tahun 2010-2014.

Dewi, R. (2017). Pembangunan Pedesaan dan Kemandirian Lokal. Asia-Pacific Journal of Public Policy, 3(2), 39-49.

Field, J. (2005). Modal Sosial. Penerbit Bina Media Perintis.

Fikriyah, N. (2017). Sistem Jaringan Distribusi Petani Budi Daya Ikan di Desa Dukuh Tunggal Glagah Kabupaten Lamongan. Disertasi. Universitas Muhammadiyah Malang.

Karundeng, T. N., Mandey, S. L., \& Sumarauw, J. S. (2018). Analisis Saluran Distribusi Kayu (Studi Kasus di CV. Karya Abadi, Manado). Jurnal EMBA: Jurnal Riset Ekonomi, Manajemen, Bisnis dan Akuntansi, 6(3).

Kasim, F. M., Nurdin, A., \& Rizwan, M. (2021). Agama, Modal Sosial dan Ketahanan Masyarakat dalam Menghadapi Bencana di Kota Banda Aceh. Jurnal Antropologi: Isu-Isu Sosial Budaya, 23(1), 66-73.

Ketaren, A. (2015). Modal Sosial Petani dalam Pertanian Berkelanjutan dalam Mendukung Ketahanan Pangan Daerah. Lhokseumawe: Unimal Press.

Lawang, R. M. (2004). Kapital Sosial dalam Perspektif Sosiologik: Suatu Pengantar. FISIP UI Press.

Mantra, I. B. (2004). Filsafat Penelitian \& Metode Penelitian Sosial. Pustaka Pelajar.

Marin, A. \& Wellman, B. (2011). Social Network Analysis: An Introduction, 11-25 dalam Scott, J. \& Carrington, P. J., Eds, The SAGE Handbook of Social Network Analysis, 601 h. Sage Publication.

Purwanto, A. (2013). Peranan Jaringan Sosial dalam Klaster Industri. Jurnal Ilmu Administrasi (JIA), 9(3).

Putra. J. J. W. (2010). Jaringan Sosial Pengusaha Tempe dalam Kelangsungan Usaha di Debengan. Skripsi. Program Studi Sosiologi Universitas Sebelas Maret.

Rochwulaningsih, Y. (2013). Tata Niaga Garam Rakyat dalam Kajian Struktural. Citra Lekha, $17(1), 59-66$.

Sholihah, F. V., Kinseng, R. A., \& Sunito, S. (2017). Dinamika Sosial Ekonomi pada Distribusi Komoditas Pisang Skala Rakyat di Jawa Barat. Jurnal Sosiologi Pedesaan, 12(1), 52-60.

Soetoprawiro, K. (2013). Pengantar Hukum Pertanian. Gapperindo.

Sugiyono (2013). Memahami Penelitian Kualitatif. Alfabeta.

Usman, H. \& Akbar, P. S. (2009). Metode Penelitian Sosial. Bumi Aksara.

Widhyharto, D. S. (2012). The Sociology Economy a Systematic Inquiry. Jurnal Pemikiran Sosiologi, 1(2), 108-113. 